\title{
Analisis Efisiensi Faktor Produksi Usaha Budidaya Ikan Bandeng (Chanos chanos) (Studi Kasus pada Alumni Peserta Pelatihan Budidaya Ikan di BPPP Banyuwangi
}

\section{Efficiency Analysis of Factors Production Milk Fish (Chanos chanos) (Case Study on Alumni Training Participants Of Fish Culture in BPPP Banyuwangi)}

\author{
Sumartin ${ }^{I}$ \\ ${ }^{l}$ Balai Pendidikan dan Pelatihan Perikanan (BPPP) Banyuwangi \\ Email : Sumartinmartin@yahoo.co.id
}

\begin{abstract}
Abstrak
Penelitian ini bertujuan menganalisis efisiensi ekonomi, teknis dan harga pada pembudidaya ikan bandeng alumni peserta pelatihan budidaya ikan di Balai Pelatihan dan Penyuluhan Perikanan (BPPP) Banyuwangi. Menggunakan analisis fungsi produksi Cobb Douglas stochastic frontier yang diestimasi dengan Metode Ordinary Least Square (OLS) bertujuan untuk mengetahui efisiensi kinerja rata-rata pelaku budidaya ikan bandeng. Estimasi dengan metode maximum likelihood $(M L E)$ bertujuan mengetahui efisiensi teknis. Untuk mengetahui efisiensi harga dapat diketahui dari nilai produk marginal (NPM) dari faktor produksi. Hasil penelitian menunjukkan efisiensi ekonomi budidaya ikan bandeng di Kab. Gresik, enam faktor produksi di daerah rasional, tetapi belum efisien karena nilai koefisien luas kolam (X1) 0.318, pupuk (X2) 0.079, kapur (X3) 0.009, benih (X4) 0.005, probiotik (X6) 0.066 dan tenaga kerja (X7) 1.311. Untuk faktor produksi pakan (X5) berada pada daerah tidak rasional karena nilai koefisien -0.017. Sedangkan variabel yang mempengaruhi inefisiensi yaitu pengalaman pembudidaya (Z1) -0,0711458, umur pembudidaya (Z2) -0,6270106 dan pendidikan formal (Z3) -0,1504381. Nilai Produk Marginal (NPM) dari faktor produksi luas tambak (X1) 0,00059 (<1), Pupuk (X2) 3,01413, kapur (X3) 3,35338, NPM faktor produksi lainnya yaitu Benih (X4) 0,00075 dan Tenaga kerja (X7) 0,03865, Pakan (X5) -0,00364, probiotik (X6) yaitu 95,1491. Ketujuh faktor produksi nilai rata-rata efisiensi harga sebesar 101,553 dan efisiensi ekonomis sebesar 2.904. Dapat disimpulkan bahwa usaha budidaya ikan bandeng belum efisien .
\end{abstract}

Kata kunci : efisiensi, ekonomi, teknis, harga, frontier, bandeng

\begin{abstract}
This study aims to analyze the economic, technical and price efficiency of milkfish farmers participating fish culture training at Center of Education and Fisheries Training Banyuwangi, analyzing covering factors affecting production efficiency. Analysis of data used in the form of production function analysis Cobb Douglas stochastic frontier which is estimated by Ordinary Least Square Method (OLS). Estimation of Cobb-Douglas production function model using OLS method to know the efficiency of the average performance of fish culture business. Estimates with the maximum likelihood (MLE) method to determining the level of technical efficiency, using the 4.7 frontier computing program developed by Coelli (1996). To know the efficiency of the price can be calculated by the value of marginal product (VMP) of production factor. The results show that the level of economic efficiency of milkfish culture business in Gresik East Java, based on the results of estimation using MLE method, the result of six factors of production is in rational area, but not yet efficient because the obtained coefficient value of each area of pond (X1) 0.318, fertilizer (X2) 0.079, lime (X3) 0.009, seeds (X4) 0.005, probiotics (X6) 0.066 and labor (X7) 1.311. While one feed production factor $(X 5)$ is in an irrational area because it has a coefficient value of -0.017. While the variables that influence inefficiency are experiential variables (Z1), age of farmers (Z2) and formal education (Z3) each have elasticity of -0.0711458; -0,6270106 and -0,1504381. The value of Marginal Product (NPM) of pond production area (X1) is $0.00059(<1)$, Fertilizer (X2) is greater than 1 ie 3,01413, lime production factor (X3) 3,35338, the other NPM factor production such as
\end{abstract}


Seed (X4) and Labor (X7), with value less than 1 (0.00075 and 0.03865), NPM Feed (X5), is smaller than one ie $-0.00364(<1)$. NPM probiotic (X6) is 95,1491 (> 1). Overall allocation of the seven factors of production is the average value of price efficiency is also more than one that is equal to 101,553 and economic efficiency equal to 2,904. it can be concluded that fish breeding business has not been efficient.

Keywords: efficiency, economy, technical, price, frontier, milkfish

\section{PENDAHULUAN}

Angka konsumsi ikan merupakan tingkat konsumsi masyarakat Indonesia terhadap komoditas ikan yang dikonversi dalam satuan $\mathrm{kg} /$ kap/ tahun. Dalam melakukan analisis angka konsumsi ikan selalu ditampilkan dengan data penyediaan ikan konsumsi pada periode waktu tertentu. Penyediaan konsumsi ikan harus selalu lebih besar dibandingkan dengan capaian angka konsumsi ikan dengan selisih yang tidak terlalu lebar serta mempunyai kecenderungan naik dari tahun ke tahun. Capaian angka konsumsi ikan pada tahun 2014 adalah sebesar 38,14 kg/kap/tahun dengan total konsumsi ikan nasional sebesar 13,072 juta ton dan pemerintah akan terus memprogramkan masyarakat untuk mengkonsumsi ikan hingga 54,49 kg/ kap/ tahun pada tahun 2019.

Produksi perikanan nasional pada tahun 2014 tercatat 14.453. 295 ton, terdiri dari perikanan budidaya 9.688.460 ton atau setara $54,09 \%$ dan perikanan tangkap 4.764 .835 ton (setara 45,96\%) dari total produksi perikanan nasional.

Total produksi dari perikanan budidaya mampu memberi kontribusi sebesar 5,17\% pada tahun 2014 . Salah satunya diperoleh dari produksi ikan bandeng. Adapun perkembangan budidaya ikan bandeng dalam kurun waktu tahun $2010 \quad-2014$ menunjukkan kinerja dengan kenaikan yang tidak signifikan dengan peningkatan produksi rata rata sebesar $0,91 \%$, gambaran produksi bandeng terhadap produk perikanan budidaya nasional dalam lima tahun dapat dilihat seperti gambar 1 .

Gambar 1 : Grafik Produksi Budidaya Bandeng terhadap produksi Perikanan Budidaya Total 2010 - 2014.

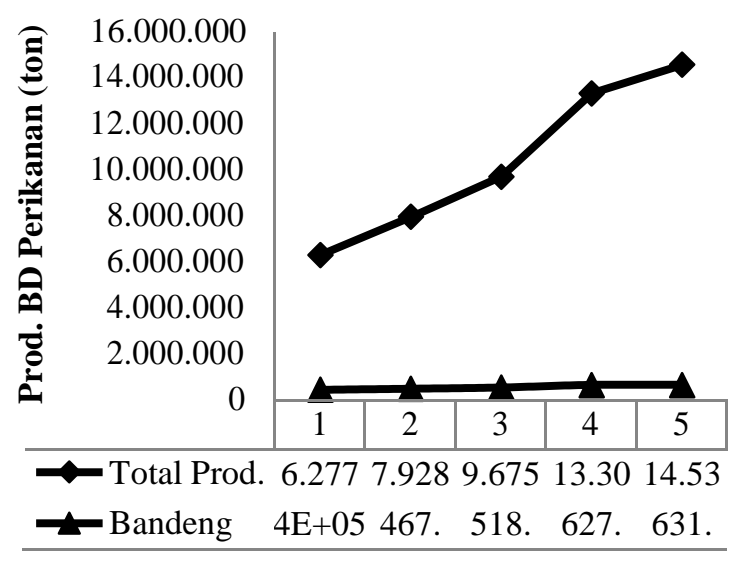


Sumber : Dirjen Perikanan Budidaya

Balai Pendidikan dan Pelatihan Perikanan (BPPP) Banyuwangi sebagai salah satu unit pelaksana teknis Badan Pengembangan SDM Kelautan dan Perikanan Kementerian Kelautan dan Perikanan memiliki tugas utama salahsatu diantaranya adalah melatih bagi para pembudidya ikan .

Sehubungan dengan hal tersebut maka perlu diketahui sampai seberapa keberhasilan para peserta pelatihan dalam melakukan kegiatan usaha budidaya bandeng setelah mengikuti pelatihan.

\section{METODE PENELITIAN}

Lokasi penelitian di Kabupaten Gresik Jawa Timur. Data primer dan sekunder dikumpulkan melalui teknik observasi dan wawancara. Penentuan sampel dilakukan dengan metode proportional sampling, dengan jumlah total responden sebesar 26 responden di tingkat Rumah Tangga Perikanan (RTP).

Penelitian ini menggunakan model fungsi stochastic production frontier Cobb-Douglas dengan parameter Maximum Likelihood Estimated (MLE) untuk menganalisis fungsi produksi. Tujuan dilakukannya analisis fungsi produksi tersebut yaitu untuk menganalisis Efisiensi Kinerja Budidaya ikan bandeng yang meliputi:

\section{A. Fungsi Produksi Frontier Stokastik dan Efisiensi Teknis}

Faktor produksi secara langsung mempengaruhi produktivitas. Adapun faktor tersebut yaitu luas kolam/tambak, pupuk, kapur, benih, pakan, obat-obatan dan probiotik, tenaga kerja . Selain itu ada pula faktor yang sifatnya tidak langsung. Faktor ini berkaitan dengan manajemen pengelolaan usaha budidaya ikan, yaitu pengalaman berbudidaya, umur pembudidaya, dan tingkat pendidikan formal pembudidaya. Model matematis fungsi produksi frontier stokastik untuk usaha budidaya perikanan dalam penelitian ini yang kemudian ditransformasikan kedalam bentuk double log natural (Ln) yaitu sebagai berikut :

$$
\begin{aligned}
& n(i)=\beta 0+\beta 1 \ln 1+ \\
& \beta 2 \ln 2+\beta 3 \ln 3+\beta 4 \ln 4+
\end{aligned}
$$


$\beta 5 \ln 5 \beta 6 \ln 6+\beta 7 \ln 7+$

$i-i$

dimana Y adalah output (bandeng) yang dihasilkan (kg), $\beta 0$ adalah

Konstanta

$\beta$ adalah koefisien, $\mathrm{X}_{1}$ adalah Luas tambak (Ha), $\mathrm{X}_{2}$ adalah Pupuk (Kg), $\mathrm{X}_{3}$ adalah $\mathrm{Kapur}(\mathrm{Kg}), \mathrm{X}_{4}$ adalah Benih (ekor), $\mathrm{X}_{5}$ adalah Pakan (Kg), $\mathrm{X}_{6}$ adalah Obat obatan dan probiotik $(\mathrm{Kg}), \mathrm{X}_{7}$ adalah Tenaga kerja (Hari kerja setara pria/HKSP), vi adalah Kesalahan yang dilakukan karena pengambilan secara acak, ui adalah Efek dari efisiensi teknis yang muncul. ui dihasilkan dari :

$$
i=\delta 0+\delta 11 i+\delta 22 i+\delta 33 i
$$

Variabel yang mempengaruhi ketidakefisienan (inefficiency) dimana Z1 adalah Pengalaman pembudidaya (tahun), Z2 adalah Umur pembudidaya ikan (tahun) dan Z3 adalah Pendidikan formal pembudidaya bandeng (tahun).

Faktor yang dilibatkan dalam model untuk memperkirakan kemungkinan yang akan muncul terhadap efisiensi teknis budidaya bandeng. Parameter dari model tersebut diatas diduga dengan metode maksimum likelihood (MLE) dengan memakai program komputasi STATA 11.1 dengan pendekatan Stochastic Frontier .

Program ini mengikuti 3 langkah prosedur pendugaan yaitu:

1. Metode Ordinary Least Square (OLS), untuk memperoleh semua nilai paramet dugaan (kecuali konstanta - $\beta 0$ ) yang tidak bias. Nilai $\beta$ ini digunakan sebagai nilai awal untuk mengestimasi model maksimum likelihood.

2. Grid search nilai $\gamma$, yang nilainya antara 0 dan 1.

3. Dengan metode algoritma Davidon-Fletcher-Powel dihitung parameter final yang diestimasi menggunakan nilai $\beta$ hasil estimasi OLS dan nilai $\gamma$ dari langkah kedua sebagai nilai awal pada prosedur iterasi untuk memperoleh nilai penduga maksimum likelihood.

\section{B. Efisiensi Harga atau Allocative Efficiency}

Menurut (Soekartawi, 2001), apabila fungsi produksi yang digunakan merupakan model fungsi produksi Cobb-Douglas, maka :

$$
\mathrm{Y}=\mathrm{A} \mathrm{X}^{\mathrm{b}}
$$




$$
\begin{gathered}
\text { Atau } \\
\operatorname{Ln} \mathrm{Y}=\operatorname{Ln} \mathrm{A}+\mathrm{b} \operatorname{Ln} \mathrm{X}
\end{gathered}
$$

maka kondisi produk marginal adalah $\partial$

$\frac{\partial \mathrm{Y}}{\partial \mathrm{X}}=\mathrm{b}$ (Koefisien Parameter)

Dalam fungsi produksi CobbDouglas, maka b disebut dengan koefisien regresi yang sekaligus menggambarkan elastisitas produksi. Dengan demikian, maka nilai produk marginal (NPM) faktor produksi X, dapat ditulis sebagai br ikut :

$$
=\frac{\mathrm{bY} \text { PY }}{X}
$$

dimana : $b$ adalah elastisitas produksi, $\mathrm{Y}$ adalah produksi, Py adalah harga produksi dan $\mathrm{X}$ adalah jumlah faktor produksi X

Efisiensi harga tercapai apabila perbandingan antara nilai produktivitas marginal masingmasing input (NPMxi) dengan harga inputnya (vi) atau "ki" = 1 . Kondisi ini menghendaki NPMx sama dengan harga faktor produksi X, atau dapat ditulis sebagai berikut : $\mathrm{NPM}=\mathrm{P}_{\mathrm{X}}$

$$
\underline{b \quad P}=P
$$

$$
\frac{b \quad P}{P}=1
$$

dimana : $\mathrm{P}_{\mathrm{X}}$ adalah harga faktor produksi X. Dalam praktek nilai Y, $\mathrm{P}_{Y}, \mathrm{X}$ dan $\mathrm{P}_{\mathrm{X}}$ adalah diambil nilai rata-ratanya, sehingga persamaan tersebut dapat ditulis sebagai berikut

$$
\frac{b^{-} P^{-}}{\mathrm{XPX}}=1
$$

Menurut Soekartawi (1994) bahwa dalam kenyataan NPMx tidak selalu sama dengan Px. Yang sering terjadi adalah sebagai berikut:

a. (NPMx / Px $)>1$ artinya penggunaan input $\mathrm{X}$ belum efisien, untuk mencapai efisiensi maka input X perlu ditambah.

b. $(\mathrm{NPMx} / \mathrm{Px})<1$ artinya penggunaan input $\mathrm{X}$ tidak efisien, untuk menjadi efisien maka penggunaan input $\mathrm{X}$ perlu dikurangi. Efisiensi yang demikian disebut dengan istilah Efisiensi harga atau allocative efficiency (AE).

\section{Efisiensi Ekonomis}

Menurut (Soekartawi, 1994) efisiensi ekonomi merupakan hasil kali antara seluruh efisiensi teknis dengan efisiensi harga/alokatif dari 
seluruh faktor input dan dapat tercapai apabila kedua efisiensi tercapai Efisiensi ekonomi usaha budidaya bandeng dapat dinyatakan sebagai berikut :

$$
\mathrm{EE}=\mathrm{ET} . \mathrm{EH}
$$

dimana : EE adalah Efisiensi
Ekonomi, ET adalah Efisiensi Teknis dan EH adalah Efisiensi Harga.

\section{HASIL DAN PEMBAHASAN}

\section{Hasil Penelitian Deskripsi Variabel Efisiensi Budidaya Perikanan}

Deskripsi variabel budidaya Bandeng (Chanos chanos) dapat dilihat pada Tabel berikut:

Tabel 1. Deskripsi Variabel Usaha Budidaya Ikan Bandeng ( $\mathrm{N}=26)$

\begin{tabular}{|c|c|c|c|c|c|c|}
\hline No & Variabel & Mean & Min & $\operatorname{Max}$ & $\begin{array}{l}\text { Std. } \\
\text { Dev }\end{array}$ & $\begin{array}{l}\text { Mean } \\
\text { Value }\end{array}$ \\
\hline 1 & Output (ikan) (kg) & 1.843 & 200 & 8.000 & 2.153 & 56.337 .981 \\
\hline 2 & Luas tambak $\left(\mathrm{m}^{2}\right)$ & 25.000 & 5.000 & 90.000 & 22.000 & 1.235 .577 \\
\hline 3 & Pupuk $(\mathrm{Kg})$ & 536 & 40 & 1.500 & 432 & 268.077 \\
\hline 4 & Kapur (Kg) & 288 & 100 & 2.000 & 642 & 287.692 \\
\hline 5 & Benih (ekor) & 135.837 & 1.000 & 1.125 .000 & $\begin{array}{l}306.74 \\
3\end{array}$ & 2.737 .629 \\
\hline 6 & Pakan $(\mathrm{Kg}$ & 1.088 & 50 & 11.840 & 4.450 & 10.910 .391 \\
\hline 7 & Obat obatan dan probiotik (1) & 17 & 3 & 100 & 23 & 136.308 \\
\hline 8 & Tenaga kerja(HKSP) & 198 & 105 & 420 & 112 & 9.513 .683 \\
\hline
\end{tabular}

Sumber : Data Primer diolah, 2016.

Rata-rata produksi usaha budidaya ikan bandeng sebesar 1.843 $\mathrm{kg}$ dengan nilai sebesar Rp. 56.337.981,- $\quad$ dari sejumlah 26 pembudidaya ikan yang diteliti. Sedangkan rata-rata luas kolam $25.000 \mathrm{~m}^{2}$ dengan nilai sebesar Rp. 1.235.577,-- lalu pupuk sebesar 536 kg dengan nilai sebesar Rp 268.077,-. Rata-rata benih 135.837 ekor dengan nilai Rp. 2.737.629,-. Kemudian probiotik rata-rata pembudidaya ikan menggunakan 17 liter dengan nilai sebesar Rp 136.308,- Tenaga kerja rata-rata 198 hksp dengan upah ratarata $\mathrm{Rp}$. 9.513.683,-.

\section{Analisis Fungsi Produksi Pendugaan Model Fungsi Produksi Menggunakan Metode Ordinary Least Square (OLS).}

Pendugaan model fungsi produksi berupa Cobb-Douglas menggunakan metode Ordinary Least Square bertujuan untuk mengetahui kinerja rata-rata dari proses produksi budidaya ikan bandeng yang dilakukan alumni peserta pelatihan budidaya perikanan. Berikut ini tabel 
parameter pendugaan fungsi produksi menggunakan metode OLS.

Hasil pendugaan fungsi produksi menggunakan OLS menghasilkan kinerja rata-rata (best fit) dengan nilai koefisien determinasi atau Adjusted $R^{2}$ sebesar 65,4 artinya hasil produksi budidaya ikan bandeng yang dilakukan dapat dijelaskan oleh variabel bebas dalam model sebesar 65,4 persen dan sisanya sebesar 34,6 persen dijelaskan oleh error atau variabel lain yang tidak terdapat pada penelitian ini.

Tabel 2. Pendugaan Fungsi Produksi Budidaya Ikan Bandeng dengan Menggunakan Pendekatan

\begin{tabular}{llll}
\multicolumn{1}{c}{ OLS. } & \multicolumn{2}{c}{ OLS } \\
\hline Variabel & Koefisien & T-hitung & Signifikansi \\
\hline Konstanta $(\ln \beta 0)$ & -3.407 & -1.450 & 0.164 \\
Luas kolam /tambak $(\ln X 1)$ & 0.318 & 1.325 & 0.202 \\
Pupuk $(\ln$ X2) & 7.995 & 1.286 & 0.221 \\
Kapur $(\ln$ X3) & 9.159 & 0.281 & 0.782 \\
Benih $(\ln$ X4) & 4.894 & 0.043 & 0.966 \\
Pakan $(\ln$ X5) & -1.660 & -0.428 & 0.674 \\
Obat obatan dan probiotik $(\ln$ X6) & 6.584 & 1.055 & 0.305 \\
Tenaga kerja (ln X7) & 1.311 & 2.870 & 0.010 \\
Adjust $R^{2}$ & 0.654 & & \\
\hline
\end{tabular}

Berdasarkan Tabel 2, dapat diketahui bahwa terdapat enam variabel yang memiliki koefisien positif, yaitu Luas tambak (X1), Pupuk (X2), Kapur ( X3), Benih (X4), Obat obatan dan probiotik (X6) dan Tenaga kerja (X7), dan ada satu variabel bernilai koefisien negatif yaitu Pakan (X5).

\section{Model Empiris Fungsi Produksi Frontier dan Efisiensi Teknis}

Untuk mengetahui kinerja terbaik (best practice) dapat diketahui dengan melakukan pendugaan fungsi produksi dengan pendekatan MLE yang dapat dilihat pada tabel 3 .

\section{Model Empiris Fungsi Produksi Frontier Budidaya Ikan Bandeng} Berdasarkan hasil pendugaan menggunakan metode MLE, dihasilkan faktor-faktor produksi yang berpengaruh nyata pada $\alpha=5$ persen, dengan nilai koefisien variabel positif yaitu Pupuk (X2), Kapur (X3) dan Obat obatan dan probiotik (X6) dan Luas tambak (X1), Benih (X4), dan Tenaga kerja (X7), berpengaruh nyata pada $\alpha=10$ $\%$ serta variabel yang memiliki 
koefisien bernilai negatif yaitu Pakan

(X5).

Tabel 3. Pendugaan Fungsi Produksi Budidaya Ikan Bandeng dengan Menggunakan Pendekatan MLE.

\begin{tabular}{|c|c|c|c|}
\hline \multirow{2}{*}{ Variabel } & \multicolumn{3}{|c|}{ MLE } \\
\hline & Koefisien & Std Error & Signifikansi \\
\hline Konstanta $(\ln \beta O)$ & -3.397426 & & -7.850362 \\
\hline Luas kolam /tambak $(\ln X 1)$ & 0.3175108 & 0.1994384 & -.0733813 \\
\hline Pupuk $(\ln X 2)$ & 0.0799525 & 0.0524788 & -.022904 \\
\hline Kapur $(\ln$ X3) & 0.0091588 & 0.0271565 & -.044067 \\
\hline Benih $(\ln X 4)$ & 0.0048936 & 0.0950071 & -.1813169 \\
\hline Pakan $(\ln$ X5) & -0.0166329 & 0.0323438 & -.0800256 \\
\hline Obat-obatan dan probiotik $(\ln$ X6) & 0.0658388 & 0.0519123 & -.0359075 \\
\hline Tenaga kerja $(\ln X 7)$ & 1.311472 & 0.3802418 & .5662121 \\
\hline Innimpy 71 & -0.0711458 & 1109233 & -0.2885515 \\
\hline 70 & -0.6270106 & 7287321 & -2.055299 \\
\hline Z3 & -0.1504381 & 1920207 & -0.5267918 \\
\hline
\end{tabular}

Berdasarkan dari Tabel 3 dapat dilihat nilai variabel penyebab inefisiensi pengalaman pembudidaya (Z1), umur pembudidaya bandeng (Z2) dan pendidikan formal pembudidaya bandeng (Z3) dengan nilai elastisits masing-masing sebesar $-0.0711458, \quad-0.6270106$ dan 0.1504381, sehingga terdapat inefisiensi teknis pada model ini, dan fungsi produksi stochastic frontier dapat menerangkan keberadaan efisiensi dan inefisiensi teknis budidaya di dalam proses produksi budidaya ikan bandeng.

Hubungan antara faktor produksi pada fungsi produksi prontier melalui pendekatan MLE dan OLS dengan tingkat efisiensi dapat dilihat pada gambar 2 .
Berdasarkan dari gambar 2 diketahui bahwa semua penggunaan faktor produksi pada fungsi produksi prontier adalah mendekati titik efisiensi, dimana tampak pada grafik MLE yang semuanya mendekati satu. Untuk fungsi produksi rata-rata hanya faktor produksi luas tambak (X1) dan tenaga kerja pada budidaya ikan bandeng yang sama dengan frontiernya yaitu 0,318 dan 1,311 . Berdasasrkan dari grafik di atas diketahui bahwa semua faktor produksi tersebut masih bisa ditingkatkan penggunaannya. 
Gambar 2 : Grafik Efisiensi penggunaan Faktor Produksi Rata-rata Budidaya Bandeng dengan frontiernya dengan pendekatan OLS dan MLE.

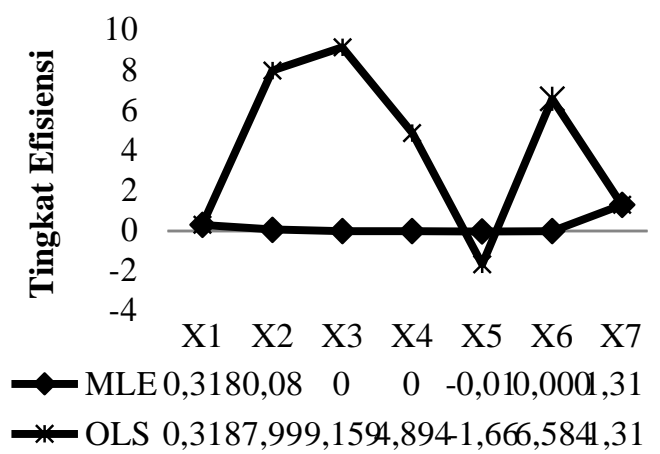

Berdasarkan fungsi produksi rata-rata, semua faktor produksi pemakaiannya masih jauh dari optimal, kecuali X5 (pakan) yang mempunyai nilai efisiensi negatif. Hal ini disebabkan karena manajemen pakan yang kurang cermat (waktu dan frekuensi pemberian, dan kuantitas tidak berdasarkan feeding ratio). Dengan demikian untuk produksi rata-rata dalam penggunaan faktor produksi semuanya masih bisa ditingkatkan, sedangkan untuk pemakaian jumlah pakan perlu manajemen yang lebih baik.

$$
\text { Data pada Tabel } 4
$$
menunjukkan bahwa rasio antara NPM dari faktor produksi Luas tambak (X1) dengan harganya dalam satu siklus budidaya adalah 0,00059 $(<1)$, NPM dari faktor produksi Pupuk (X2) adalah lebih kecil dari 1 yaitu sebesar 3,01413, NPM dari faktor produksi kapur (X3) sebesar 3,35338, NPM faktor produksi lainnya yaitu Benih (X4) dan Tenaga kerja (X7), dengan nilai yang lebih kecil dari 1 (0,00075 dan 0,03865), NPM Pakan (X5), adalah lebih kecil dari satu yaitu $-0,00364(<1)$. NPM Obat obatan dan probiotik (X6) yaitu 95,1491 (>1) .

Tabel 4. Nilai Efisiensi Harga dan Efisiensi Ekonomis Usaha Budidaya Ikan Bandeng

\begin{tabular}{llll}
\hline \multicolumn{3}{l}{ Koefisien } & \multicolumn{3}{c}{ Rasio Nilai Produk } \\
\hline \multicolumn{5}{c}{ Marjinal } \\
$\beta 1$ & 0,318 & NPM1 & 0,00059 \\
$\beta 3$ & 9,995 & NPM2 & 3,01413 \\
$\beta 4$ & 4,894 & NPM4 & 0,00075 \\
$\beta 5$ & $(1,660)$ & NPM5 & $-0,00364$ \\
$\beta 6$ & 6,584 & NPM6 & 95,1491 \\
$\beta 7$ & 1,311 & NPM7 & 0,03865 \\
Rata-rata Efisiensi & 3,35338 \\
Teknis (ET) & & $\mathbf{4 , 0 8 5 9}$ \\
Rata-rata Efisiensi & $\mathbf{1 8 , 1 1 8 4}$ \\
Harga/Alokatif (EA) \\
Rata-rata Efisiensi \\
Ekonomis ( EE = ET x \\
EA)
\end{tabular}

Secara keseluruhan dari ketujuh faktor produksi tersebut nilai ratarata efisiensi harga juga lebih dari satu yaitu sebesar 101,553 dan efisiensi ekonomis sebesar 2.904 . maka dapat disimpulkan bahwa usaha 
pembudidaya ikan bandeng belum efisien .

\section{Pembahasan Hasil Penelitian Analisis efisiensi produksi rata- rata dengan frontiernya pada budidaya ikan bandeng. \\ Berikut ini model stochastic frontier produksi budidaya ikan bandeng dan interpretasinya. \\ $\ln Y=-3.397+0.318 \ln X 1+0.079 \ln X 2+$ $0.009 \ln X 3+0.005 \ln X 4-0.017 \ln X 5+$ $0.066 \ln X 6+1.311 \ln X 7+v i-u i$}

\section{Luas Tambak (X1).}

Luas tambak memiliki pengaruh positif dan berpengaruh secara signifikan terhadap produksi budidaya bandeng. Nilai elastisitas luas tambak terhadap produksi sebesar 0,318, hal ini menunjukan bahwa dengan meningkatkan satu persen luas lahan yang diinvestasikan, dapat menaikkan produksi usaha budidaya ikan bandeng yang dilakukan sebesar 0,318 persen. Hasil pendugaan di atas dapat menjelaskan bahwa elasatisitas luas tambak pada fungsi produksi stochastic frontier sama dengan elastisitas luas tambak pada fungsi produksi rata-rata, yaitu 0,318 . Hal ini menunjukkan bahwa pengunaan luas tambak pada fungsi produksi stochastic frontier sama elastisnya dengan penggunaan luas tambak pada fungsi produksi ratarata. Namun dilihat dari nilai elastisitas luas tambak yang kurang dari satu dengan arah positif, maka dapat dikatakan bahwa pengaruh luas tambak terhadap produksi budidaya ikan bandeng bersifat inelastis.

Penggunaan faktor produksi luas tambak dapat diartikan bahwa rata-rata luas tambak masih bisa ditingkatkan, dengan catatan apabila faktor produksi yang lain bersifat centrisparibus. Jumlah rata-rata luas tambak yang diinvestasikan pembudidaya ikan bandeng adalah $25.000 \mathrm{~m}^{2}$ dengan nilai rata-rata $\mathrm{Rp}$ 1.235.577,- Sesuai dengan pendapat (Soekartawi, 1994) yang menyatakan bahwa jika nilai Elastisitas Produksi (EP) $\geq 0 \leq 1$, maka produksi berada pada daerah II yaitu daerah rasional. Dalam kondisi demikian pembudidaya masih bisa meningkatkan penggunaan faktor produksi tersebut.

\section{Pupuk (X2).}

Pemupukan pada tambak yang akan dibudidayakan ikan bandeng dilakukan pada awal sebelum benih ditebar, dengan tujuan memacu 
pertumbuhan pakan alami diperairan.

Pupuk memiliki pengaruh yang signifikan terhadap produksi budidaya ikan bandeng dan memiliki arah koefisien positif dengan nilai elastisitas sebesar 0,080. Hal ini menunjukan bahwa dengan meningkatkan satu persen besar modal yang diinvestasikan untuk pupuk, dapat menaikkan produksi usaha budidaya ikan bandeng yang dilakukan sebesar 0,080 persen.

Berdasarkan hasil pendugaan di atas dapat menjelaskan bahwa elasatisitas pemberian pupuk dalam budidaya ikan bandeng pada fungsi produksi stochastic frontier lebih besar dari elastisitas pupuk pada fungsi produksi rata-rata, yaitu 7,995. Hal ini menunjukan bahwa penggunaan pupuk pada fungsi produksi stochastic frontier lebih elastis dibandingkan dengan penggunaan pupuk pada fungsi produksi rata-rata. Karena nilai elastisitasnya tidak sama dengan satu dan bernilai positif maka berarti penambahan pemakaian jumlah pupuk masih memungkinkan guna meningkatkan produksi budidaya bandeng yang dilakukan .
Hasil penelitian untuk nilai elastisitas pupuk yang tidak sama dengan satu, maka dapat dikatakan bahwa penggunaan pupuk bersifat inelastis. Jumlah rata-rata modal yang diinvestasikan pembudidaya ikan bandeng untuk pupuk adalah Rp 268.077. Hal ini sesuai pendapat (Soekartawi, 2003) yang menyatakan bahwa jika nilai Elastisitas Produksi (EP) $\geq 0 \leq 1$, maka produksi berada pada daerah II yaitu daerah rasional. Dalam kondisi demikian pembudidaya masih bisa meningkatkan penggunaan faktor produksi tersebut.

\section{Kapur (X3)}

Pengapuran kolam biasa dilakukan oleh pembudidaya ikan bandeng pada waktu jeda antara waktu panen dengan waktu tebar untuk siklus berikutnya. Pengapuran bertujuan untuk meningkatkan $\mathrm{pH}$ tanah yang rata -rata memilki ph dibawah netral (7). Kapur memiliki pengaruh yang positif terhadap produksi budidaya ikan bandeng, dengan nilai elastisitas yang ditunjukkan sebesar 0,009. Hal ini menunjukan bahwa dengan meningkatkan satu persen jumlah 
kapur yang diberikan dengan input lainnya tetap, maka dapat meningkatkan produksi budidaya ikan bandeng sebesar 0,009 persen.

Berdasarkan hasil pendugaan di atas dapat menjelaskan bahwa elasatisitas penggunaan kapur pada fungsi produksi stochastic frontier lebih kecil dari elastisitas kapur pada fungsi produksi rata-rata, yaitu 9,159. Hal ini menunjukan bahwa penggunaan kapur pada fungsi produksi rata-rata lebih elastis dibandingkan dengan penggunaan kapur pada fungsi produksi stochastic frontier. Namun dilihat dari nilai elastisitas penggunaan kapur yang tidak sama dengan satu, maka dapat dikatakan bahwa penggunaan kapur bersifat inelastis.

Mengacu pada hasil analisis, maka penggunaan julah kapur masih bisa ditingkatkan karena masih terdapat rentang antara elastisitas produksi prontier dengan elastisitas pemakaian kapur rata-rata. Berdasarkan pemantauan dan wawancara langsung dengan responden, rendahnya pemakaian kapur antara prontir dengan rata-rata lebih sebabkan kerena kesulitan sarana transportasi untuk pengangkutan kapur ke lokasi tambak budidaya ikan bandeng.

\section{Benih (X4)}

Benih memiliki pengaruh positif dan signifikan terhadap produksi budidaya bandeng. Nilai elastisitas benih terhadap produksi adalah sebesar 0,005, hal ini menunjukan bahwa dengan meningkatkan satu persen jumlah benih yang diinvestasikan, dapat meningkatkan produksi usaha budidaya bandeng yang dilakukan sebesar 0,005 persen.

Berdasarkan hasil pendugaan di atas dapat menjelaskan bahwa elasatisitas jumlah benih pada fungsi produksi stochastic frontier lebih kecil elastisitas dibandingkan dengan fungsi produksi rata-rata, yaitu 4,894. Hal ini menunjukan bahwa elastisitas pemakaian benih pada fungsi produksi stochastic frontier elastisnya lebih rendah dibandingkan dengan leastisitas pemakaian benih pada fungsi produksi rata-rata.

Hasil analisis untuk nilai elastisitas jumlah pemakaian benih yang tidak sama dengan satu dan dengan arah positif, maka dapat dikatakan bahwa pengaruh 
pengunaan jumlah benih terhadap produksi budidaya ikan bandeng bersifat inelastis. Berdasarkan pendugaan tersebut di atas maka penambahan jumlah benih masih sangat terbuka banyak, mengingat range antara rata-rata produksi dengan prontiernya masih terdapat jarak yang jauh. Jumlah rata-rata penebaran 135.837 ekor benih pada pembudidaya ikan bandeng dengan nilai rata -rata $\operatorname{Rp} 2.737 .629$.

\section{Pakan (X5)}

Pakan memiliki pengaruh negatif, namun tidak berpengaruh signifikan terhadap produksi budidaya bandeng. Nilai elastisitas pakan terhadap produksi budidaya ikan bandeng adalah -0.017. Hal ini menunjukan bahwa dengan meningkatkan satu persen jumlah pakan yang diberikan dengan input lainnya tetap, maka dapat menurunkan produksi budidaya ikan bandeng sebesar -0.017 persen.

Berdasarkan hasil pendugaan di atas dapat menjelaskan bahwa elasatisitas pakan pada fungsi produksi stochastic frontier lebih kecil dari elastisitas pakan pada fungsi produksi rata-rata, yaitu -
1.660. Hal ini menunjukan bahwa penggunaan pakan pada fungsi produksi rata-rata lebih elastis dibandingkan dengan penggunaan pakan pada fungsi produksi stochastic frontier. Namun dilihat dari nilai elastisitas pakan yang tidak sama dengan satu dan dengan nilai elastisitas negatif, maka dapat dikatakan bahwa penggunaan pakan bersifat inelastis. Hal ini berarti bahwa jumlah pakan yang diberikan harus dikurangi.

\section{Obat-obatan dan Probiotik (X6)}

Nilai elastisitas obat-obatan dan probiotik terhadap produksi budidaya ikan bandeng adalah 0,.066 . Hal ini menunjukan bahwa dengan meningkatkan satu persen jumlah obat-obatan dan probiotik yang diberikan dengan input lainnya tetap, maka dapat meningkatkan produksi budidaya ikan bandeng sebesar 0,066 persen.

Hasil pendugaan di atas dapat menjelaskan bahwa elasatisitas obatobatan dan probiotik pada fungsi produksi stochastic frontier lebih kecil dari elastisitas obat-obatan dan probiotik pada fungsi produksi ratarata, yaitu 6,584. Penggunaan faktor 
produksi obat-obatan dan probiotik pada fungsi produksi rata-rata lebih elastis dibandingkan dengan penggunaan obat-obatan dan probiotik pada fungsi produksi stochastic frontier. Namun dilihat dari nilai elastisitas penggunaan obatobatan dan probiotik yang tidak sama dengan satu, maka dapat dikatakan bahwa penggunaan obat-obatan dan probiotik bersifat inelastis. Berarti bahwa jumlah penggunaan factor produksi obat obatan dan probiotik masih bisa ditingkatkan

\section{Tenaga Kerja (X7)}

Tenaga kerja berpengaruh positif, dan signifikan padata taraf kepercayaan $90 \%$ terhadap produksi budidaya ikan bandeng . Nilai elastisitas tenaga kerja terhadap produksi budidaya ikan bandeng adalah 1,311. Hal ini menunjukan bahwa dengan meningkatkan satu persen jumlah tenaga kerja yang diberikan dengan input lainnya tetap, maka dapat meningkatkan produksi budidaya ikan bandeng sebesar 1,311 persen.

Hasil pendugaan di atas menjelaskan bahwa elasatisitas tenaga kerja pada fungsi produksi stochastic frontier sama dengan elastisitas tenaga kerja pada fungsi produksi rata-rata, yaitu 1.311. Hal ini menunjukan bahwa penggunaan tenaga kerja pada fungsi produksi stochastic frontier sama elastis dengan penggunaan tenaga kerja pada fungsi produksi rata-rata.

Berdasarkan hasil analisis nilai elastisitas penggunaan factor produksi tenaga kerja yang lebih besar dari satu, maka dapat dikatakan bahwa penggunaan tenaga kerja bersifat inelastis. Berarti bahwa jumlah tenaga kerja yang diberikan masih memungkinka untuk ditambah. Hal ini sesuai pendapat (Soekartawi, 2003) yang menyatakan bahwa jika nilai Elastisitas Produksi $(\mathrm{EP}) \geq 1$, maka produksi berada pada daerah I yaitu daerah tidak rasional. Dalam hal ini bahwa setiap penambahan satu persen tenaga kerja akan dapat meningkatkan produksi yang lebih besar dari satu persen yaitu 1,311 persen. Dalam kondisi demikian pembudidaya masih bisa menambahkan penggunaan faktor produksi tenaga kerja. 
Variabel Penyebab Inefisiensi (Z1, Z2 dan Z3)

Variabel yang mempengaruhi ketidak efisienan (inefficiency) pada budidaya ikan bandeng yaitu variabel Pengalaman pembudidaya (Z1), umur pembudidaya perikanan dan pendidikan formal (Z3) masing masing memiliki elastisitas sebesar 0,$0711458 ;-0,6270106$ dan 0,1504381 .Hal ini artinya bahwa setiap ada penambahan satu persen lama pengalaman pembudidaya, satu persen bertamah umur pembudidaya perikanan dan satu persen penambahan pendidikan pormal pembudidaya maka akan mampu menekan angka inefisiensi masing masing 0,071 pesen, 0,627 persen dan 0,150 persen terhadap produksi. Hal ini sesuai dengan pendapat yang disampaikan oleh (Rojvithee, 2005) yang menyatakan bahwa pendidikan seumur hidup berarti pendidikan yang dihasilkan dari integrasi formal, non formal, dan pendidikan informal, sehingga menciptakan kemampuan dan mengembangkan kualitas terus menerus seumur hidup. Oleh karena belajar itu bagian dari kehidupan yang terjadi di semua waktu dan di semua tempat.

\section{KESIMPULAN}

Berdasarkan hasil analisis hasil penelitian faktor produksi pada usaha budidaya lele dapat disimpulkan sebagai berikut :

1. Tiga faktor produksi yaitu luas lahan, benih dan pakan berada di daerah rasional, tetapi secara teknis belum efisien karena diperoleh nilai koefisien masing masing yaitu luas kolam 0.198 , benih 0.456 dan pakan 0.423 , sehingga masih memungkinkan untuk penambahan ketiga faktor froduksi tersebut untuk meningkatkan produksi.

2. Sedangkan empat faktor produksi lainnya yaitu pupuk, kapur, probiotik dan tenaga kerja secara teknis tidak efisien, karena berada di daerah irasional dengan diindikasikan dengn perolehan nilai koefisien negatif, yaitu faktor produksi pupuk -1.74, kapur -4.18, probiotik -1.54, tenaga kerja -9.59 , sehingga harus mengurangi ke empat faktor produksi tersebut guna meningkatkan produksi.

3. Secara keseluruhan efisiensi harga yang dicapai yaitu sebesar 0,21796 dan efisiensi ekonomis 
sebesar 3,48147 atau dengan kata

lain belum efisien karena nilai $\mathrm{EE}>1$.

\section{DAFTAR PUSTAKA}

Boyd, C.E. 1992. Water Quality In Ponds For Aquaculture. Bermingham Publishing Co Bermingham, Alabama.

Coelli T.J. 1996. A Guide to Frontier Version 4.1. : A Computer Program For Stochastic Frontier Froduction and Cost Fungction Estimation. Centre for Efficiency and Productivity Analysis. University of New England Armidale New South Wales.

Coelli T.J, Rao PSD, Battese GE. 1998. an Introduction to Efficiency and Product Analysis. London: Kluwer Academic Publishers.

Durborow, R.M. 2000. Catfish Farming in Kentucky Associate Professor State Extension Specialist for Aquaculture Aquaculture Program Kentucky State University Frankfort, Kentucky.

Ghozali Imam. 2007. Aplikasi Analisis Multivariat Edisi 4 dengan Program SPSS BP Unversitas Diponegoro Semarang.

Gujarati Damodar N . 1995. Third Edition Basics Econometrics, McGrawHill New York.

Halim Abdul and Ali Md. Mozahar . 1998. Improving
Agricultural Extension. A reference manual, Food and Agriculture Organization of the United Nations Rome.

Kementerian Kelautan dan Perikanan . 2013. Laporan Tahunan Direktorat Produksi Tahun 2013, Direktorat Jenderal Perikanan Budidaya, Kementerian Kelautan dan Perikanan

Kemeenterian Kelautan dan Perikanan. 2010. Peraturan Menteri Kelautan dan Perikanan Republik Indonesia Nomor Per. 06/MEN/2010, tentang Rencana Strategis Kementerian Kelautan dan Perikanan Tahun 2010 - 2014 Menteri Kelautan dan Perikanan Republik Indonesia.

Moeheriono. 2010. Pengukuran Kinerja Berbasis Kompetensi Competency Based Human Resource Management, Galia Indonesia Bogor.

Natalie L. Shipley, Mary Jo Jackson , and Sharon Larisa Segrest. 2010. The Effects of Emotional Intelligence, Age, Work Experience, and Academic Performance, University of South Florida St. Petersburg.

PPSUB. 2009. Pedoman Umum Penulisan Thesis dan Disertasi , Program Pasca Sarjana Universitas Brawijaya Malang.

Pusat Data Statistik dan Informasi. 2015. Analisis Data Pokok Kelautan dan 
Perikanan 2015.

Kementerian Kelautan dan Perikanan.

Ravi Shankar Piska and S. Jithender Kumar Naik. (2005). Fresh Water Aquaculture Fisheries, II year Paper I Intermediate Vocational Course State Institute of Vocational Education and Board of Intermediate Education Koti Osmania University Hyderabad 500001.

Soekartawi. 2003. Teori Ekonomi Produksi : dengan pokok bahasan Analisis Fungsi Produksi Cobb-Douglas, Raja Grafindo Persada Jakarta.

Sugiono, 2002. Statistik untuk Penelitian, Alfabeta, Bandung. 